\title{
Public transport system in the capital of Kyrgyzstan: current situation and analysis of its performance
}

\author{
A. Kadyraliev \\ Faculty of Economics and Administration, Masaryk University, \\ Brno, Czech Republic
}

\begin{abstract}
Kyrgyzstan, as a 'post-socialist' country, experienced the problems common to all such countries when it gained independence in 1991. The country instantly faced new challenges in its transition from central planning economy to an open market economy almost overnight. Change of this magnitude necessitated change in every branch of the economy including the public transport sector. Bishkek, as the capital, faced numerous difficulties in terms of socio-economic conditions. The city needed an increase in transport passenger services but to achieve this, more public transport vehicles were required because of increasing domestic migration concentrated mostly toward the capital. How to do this in an economy facing massive upheaval? This paper examines the current situation of public transport system in the capital of Kyrgyzstan and its changes after collapse the Soviet Union. In addition, this research performs a dynamic analysis of tariff system and changes in number of municipal and private operators' vehicles, also their performances are included.

Keywords: public transport, municipal, private, fare, bus and minibus, urban, subsidy.
\end{abstract}

\section{Introduction}

Kyrgyzstan is a small country in Central Asia with 5,4 mln population [19]. It is administratively divided into seven provinces (oblast) and twenty-five cities. Bishkek as the capital and largest city in the country has particular importance, both for the cultural and industrial development of the country. However, this dynamic development of the city is hampered by a number of problems. The 
most critical of these is the provision of urban public transport for its residents and non-residents, including development of the transport infrastructure, the lifesupport system of the city.

The terms "urban mass transportation", "urban public transport, and "transit" are usually understood to mean conventional transit, i.e., subways (metros), streetcars (trams), autobuses, trolleybuses, and in some cases, commuter railroads [14]. Thus, public transport planning is about arranging for people to have accessibility to where they want to go, easily, quickly and in large numbers" [1]. Public transport is therefore vital for the vast majority without access to private transport [4].

Urban public transport (UPT) in Bishkek consists of trolleybuses, buses and minibuses; the so-called "marshurutki". It covers city centre, suburbs and adjacent zones of the Chui region.

Generally speaking, many people believe that public transport service in Bishkek has declined in quality. One of the main factors in this deterioration of UPT services is lack of financial resources, low fares on services, a large number of exempt and concessionary passengers $[9,13,21]$. Such kind of phenomena was observed also in neighbour states such as Kazakhstan [8], Uzbekistan [11] and in other Former Soviet Union countries [6, 15] after the 1990s. Consequently, these factors led to deteriorating service from municipal operators and the growth of minibus services provided by private operators.

Bishkek, the capital of the Kyrgyz Republic with 832,000 officially registered residents [19], by expert assessment this digit might be at around 1,2 $\mathrm{mln}$ as many people have no registration, particularly in a newly appeared semi-formal settlements. Since 1990, with the collapse of the central planning system, the city has faced the dilemma of rapid urban growth. It is clear that the rapid urban growth of population in Bishkek, primarily related to the domestic migration within the country where citizens are seeking work and housing. An indicator of economic crisis and lack of regional infrastructure, internal migration has a negative impact on the geopolitical situation in Kyrgyzstan [16]. The inner population redistribution from villages to the city, which represents more than $60 \%$ of the bulk of migration, is a visual example reflecting structural transformation defects occurring in the economy [3]. This is accompanied by an ever increasing growth in passenger volume not only because of the greater population but also because of the need for greater frequency of trips in pursuit of work and work related travel.

Expansion of urban areas in the last two decades in Bishkek consists primarily of the construction of new semi-formal settlements (novostroiki) on the outskirt of the city to cope with population increase. This has complemented in creating difficulties in the organization of passenger services provoking city planning administration to reform the public transport sphere over the last few years, but the results leave much to be desired. To date exist forty seven novostroek with about 300 thousand inhabitants [17], mostly without infrastructure.

Iles points out that the provision of public transport in urban areas has become a major problem in most developing countries, in some respects more so 
than in developed countries [4]. A major cause is rapid urban population growth, resulting in increased demand with which many transport systems are unable to cope adequately, compounded by low levels of income, inadequate road infrastructure, and uncontrolled use of private transport, severe traffic congestion, and inadequate and inefficient public transport systems [4]. And Bishkek is not excluded from these dilemmas.

In spite of significant research in different countries with the study of different approaches; there is a common problem in the interpretation of urban public transport provision over the world. However, each has a different level of decision-making. And it is obvious that better provision of urban public transport depends on a level of government support i.e. financing its capital and operation costs as public transport cannot be profitable [6]. In addition, as Kominek concluded in his study about urban transport in transition countries, including Kyrgyz Republic, the importance of institutional strengthening of local authorities [15]. Also, the World Bank reported that the institutions dealing with urban transport regulation and sector management in Bishkek are weak and, in some cases, not independent from the operators and contractors [21].

\section{The role of urban transport today}

Transport has traditionally been seen as not just an ordinary commodity, but also as a prerequisite for many other economic and social activities [7]. But, the role of public transport has changed over time. Growing urban population needs in more mobility than ever, therefore it is necessary to understand the importance of urban public transport and its better provision for society. Unfortunately, city authorities not only of Bishkek, but also throughout the country have been involved in a slow manner of public transport development, instead of providing the backbone for the movement of passengers. The role of Urban Public Transport today is to be available as an alternative to the private automobile [7]. The continuously increasing number of private automobiles on the roads of Bishkek creates difficulties for movement. As private car users have increased in numbers they are becoming less dependent on public transport, but as land uses have become more orientated to the private car, the need to travel to shops, work or for leisure for example, has increased [1]. According to statistics [19], the number of motor cars in the country has increased twofold over the last five years. By the end of 2010 there were accounted 444,1 thousand motor cars throughout the country. Only nine percent of the total numbers of motorcars belong to organizations and the other ninety one percent to individuals. According to the master plan the road capacities of the capital were designed for about fifty thousand motorcars, thus its available capacity has been overloaded almost threefold, as approximately 150,0 thousand motor cars daily moves in the city [9].

\subsection{Minibus sector}

The capital's public transport system was established in during the period of Soviet Union governance under severe closed market conditions. The population 
had been served by monopolist public transport enterprises. That system was not so unique, but was welcomed by the populace because it satisfied their transport needs at the time. Nevertheless, capital needed to provide an up-to-date transport system with more comfortable vehicles and better services more in keeping with users' expectations was not invested.

When the country gained independence in 1991, the new open market gave opportunities for all branches of economy to start to act under competitive trading conditions. Competition was permitted in all industries including passenger transport services. Most of the public enterprises were privatised while some were transformed into joint-stock companies. While the country underwent difficulties and faced challenges under the new open market economy, the population too faced challenges.

It is hard to say if there were any fundamental changes in the public transport sector in terms of improving and expanding the passenger transport services not only within the capital but also throughout the country since gaining independence. Although there have been moderate improvements since 2009 undertaken by Bishkek city administration, such as purchasing new vehicles, giving of privileged routes for municipal vehicles in the centre of the city resulted in ipso facto reduction of minibuses from core centres.

Urban public transport dilemmas in Bishkek are seen like long queues at the bus stops, particularly in rush hour, most of vehicles are old, badly maintained, and unreliable and most of them are crowded. This description mostly belongs to minibuses. The minibuses have up to twenty passengers crushed into their twelve seats where even no handrails, the passengers at the bus stops rush at each bus and minibus as they approach. Alighting and boarding of minibuses are by passengers' request even in unauthorised zones. The current situation and behaviour of minibuses in Bishkek is somehow similar to the Yerevan case, Armenia [5], Tashkent, Uzbekistan [11], and some African cities [4]. The city authorities of Bishkek have declared that minibuses are one of the main factors of traffic congestion. About three thousands minibuses carry out 65 percent of the total urban public transport volume [9]. Thus, they play an important role in the provision of public transport service in Bishkek; simultaneously have a great role in the traffic congestion.

The first private minibuses appeared at the beginning of the 1990s. The private minibus sector initially occupied a small share of the passenger transport market. Subsequently, as the population increased in the capital looking for work, so too did the minibus share of the market. The domestic migration within the country impacted on city's expansion of Bishkek and emerging novostroek in the outskirts of the capital [16]. Areas previously used for agriculture were also utilized as housing. The city became more congested than before and metropolitan residents needed in more public transport vehicles in order to travel around the new expanded city and to the centre. This was the niche in the market that entrepreneurial minibus operators occupied. Although the vehicles were second-hand foreign minibuses, most of which were not designed as passenger carriers originally, citizens welcomed the service and minibuses played a dominant role in the passenger transport market until city administration 

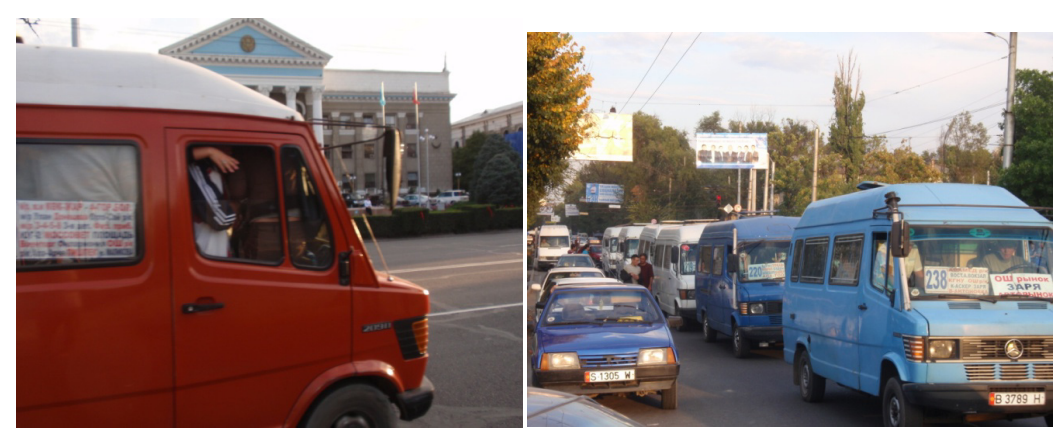

Figure 1: Minibuses in the city centre.

commenced reforms in early 2009 in order to implement the decree of the President of Kyrgyz Republic "On development strategy country 2009-2011" [9]. With the purchasing of new buses, trolleybuses and the re-design of existing routes giving preference to municipal vehicles in the core centre, the private sector began to be displaced from the central streets of the capital and redistributed to the routes in novostroikah on the outskirts of city where municipal buses are not able to serve due to poor roads. Consequently the number of private minibuses diminished as a result of these reforms, this led to a decline in their performance.

As in the former capital of Kazakhstan, Almaty, the minibus sector made a vital contribution to the public transport supply in the years when the big bus services disappeared [8]. The minibus sector plays a major role in the market of

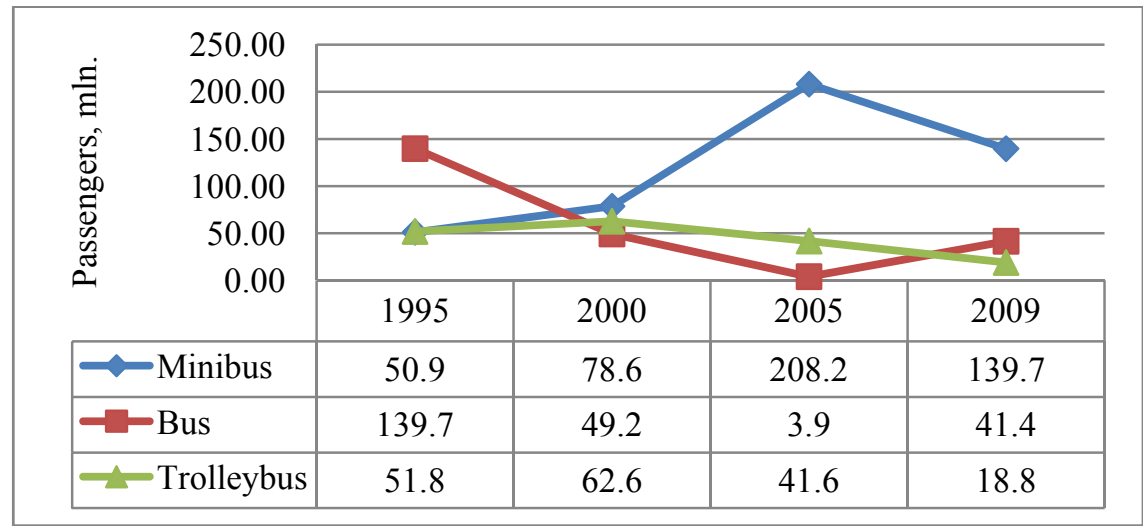

Source: Bishkek City Transport Department

Figure 2: $\quad$ Performance of each mode of transport. 
all Commonwealth Independent States (CISs), and the sector established itself very quickly, and proved to be sustainable without government subsidises. As city authorities of Bishkek consider that minibuses are inappropriate due to increased traffic congestion in the city, at the same time they recognise that minibuses are unlikely to disappear from the market in the next few years. The big bus sector is not able to cover minibus performance. The number of minibuses fluctuates day-by-day; an average vehicles functioning on the routes, accounted at 3000 with $4377,8 \mathrm{~km}$ line length and 118 routes.

Kominek did a comprehensive overview in transition countries, and pointed out that CISs have the largest share of urban transport provided by private companies [15]. But, as a study of Gwilliam showed, despite the growth of the private sector in Bishkek, all is not entirely well and the quality of the public sector vehicles has declined, and operating behaviour of some private operators is aggressive and dangerous as a result of a plethora of separate operators overlapping on major sectors of routes [13]. The poor quality of the majority of minibuses, increased second hand private cars have impacted to ecological problems for the city. This is in turn causes serious air pollution and noise as more than 80 percent of all emissions into the atmosphere come from transport [12]. In 2009, 15 January, Jogorku Kenesh (Kyrgyz Parliament) adopted an "Ecological Code" which became a regulatory framework in the field of environmental aspect [18]. The new code introduced rules that will encourage the use of environmentally friendly technologies and techniques. Since that time, the minimum age of motorcars imported into the country has been limited at ten years.

\subsection{Re-emerged bus sector}

After the year 2000 many buses that were purchased in 1980s were no longer in service [9] and not able to provide further passenger services in Bishkek. In order to provide passenger transport and continue its activities, the Bishkek Passenger Transport Agency purchased more than 50 second-hand German buses during 1995-96 periods. They purchased heavy duty vehicles such as "Mann", "Zetra", and "Mercedes" to increase capacity using funds from foreign investors" programmes. The newly purchased European second-hand buses were assessed to have a productive service life of no more than ten years and as a result they were retired from service in 2005-06 [9].

At the beginning of 1999 the public trolleybus organization was still operating about 180 vehicles from a nominal fleet of just over 200 vehicles and the public bus undertaking (Avtokombinat) was running between 70 and 100 large and medium sized buses [13]. From 2005-2009 only twenty buses remained in service having been reduced from 242 in 1995. In 2009 Bishkek Mayor purchased 353 buses manufactured in China to revitalise the almost nonexistent service, reducing waiting time for passengers and facilitating ease of movement around the city. The number of passengers increased dramatically from 3.9 million to 41.4 million in the space of only 4 years. Most of this increase can be attributed to passengers moving from the minibus sector to the big bus. At 
present time, bus routes function on 14 routes with 200 vehicles an average, total line length reaches $444,8 \mathrm{~km}$.

The re-emerged big bus sector in the routes is a result of a bilateral agreement between the governments of Kyrgyzstan and China. Part of the vehicles is granted by China and the rest of the buses purchased by long-term credit. New buses have taken privilege rights in the core lines; this has resulted in the increase of their performance. But, some bus and minibus routes duplicate each other which force competition on the driving way to capture clients. This creates dangerous conditions and insecurity for passengers. According to the Transport Department time-table of bus and minibus routes, the duplicated routes are forty percent approximately. Therefore, it is necessary for coordinated work between private and municipal operators in order to design a well planned time-table. However, given the huge number of minibuses it would create extreme difficulties to make a consistent schedule of routes between municipal and private carriers. Currently, information about municipal and private carriers' routes is not available at bus stops.

\subsection{Electric transport}

There is only one mode of electric transport in Kyrgyzstan - the trolleybus. Three cities are served by the current mode of transport. The trolleybus service is operated by a single monopolist operator in all cities of the country. This sector carries a significant part of low income riders similar to the bus sector. Both quality and quantity indicators have been dropped since 1990s. According to Bishkek City Transport Department, there remained 9 routes from 18 and 75 vehicles from 170 in the trolley fleet.

Only three trolleybuses function in Naryn city on the one route, the length of line is barely $5 \mathrm{~km}$; there is no any depot; fleets are parked in the street. In Osh city - second south capital, there are two trolleybus lines with $46 \mathrm{~km}$ line length in total, the fleet number is about twenty two. The biggest trolleybus operator is located in Bishkek with 237,6 line length and 9 routes. No new purchases were made in the trolleybus fleet after the 1990s. Rather the fleet was constantly repaired and maintained but each year fewer vehicles were available for passenger services until only half the fleet remained. During this period, the Japanese nation provided a grant to the nation of Kyrgyz for the purchase of trolleybuses, this was the first updates of the fleet after the 1990s in Bishkek and a little in Osh routes. These trolleybuses displayed this information prominently. Another updating took place in 2008-09 when Bishkek Mayor purchased lowfloor trolleybuses of Belarus production. This purchase complemented the existing trolleybus fleet, but the volume of performance remains unchanged due to a poor management system and ineffective tariff policy. As this sector carry out a significant part, the extent and concessionary passengers similar to bus sector, consequently suffer from real fare collection which in turn hits their balance negatively. 


\section{Tariff system}

Fares on public transport in Bishkek have been frozen for ten years at 3 soms (national currency) for bus and trolley travel per trip regardless of length of trip and at 5 soms for minibus trips. Increasing the tariff is an issue that is repeatedly raised particularly by the both private and public sector in light of increasing costs. To date, this issue remains unresolved with city officials believing the population is unable to bear the burden of increasing travel cost until other factors in the economy are resolved such as wage rates. According to statistics by March 2010, an average wage rated at 6335 soms or 140 US dollars.

Table 1: Dynamic of changes in tariff for UPT and price for fuel (som/KGS).

\begin{tabular}{|l|c|c|c|c|c|c|}
\hline & 2005 & 2006 & 2007 & 2008 & 2009 & 2010 \\
\hline Bus & 3 & 3 & 3 & 3 & 6 & 6 \\
\hline Trolleybus & 3 & 3 & 3 & 5 & 6 & 6 \\
\hline Minibus & 5 & 5 & 5 & 5 & 8 & 8 \\
\hline $\begin{array}{l}\text { Price for fuel } \\
\text { per litre (diesel) }\end{array}$ & 17,74 & 19,77 & 20,75 & 30,64 & 23,40 & 35,6 \\
\hline
\end{tabular}

Source: Bishkek City Transport Department

From the table we can analyse the disparity between the price for travel and fuel (bus and minibus) in the sequence. The price of fuel has increased dramatically whereas fares have been raised very slightly. As fares are controlled and set by city authorities, changes/increases in tariff have to be recommended by the Mayor of Bishkek, then considered by the Committee for Antimonopoly Policy, and finally must be approved by the Bishkek city council "Shaardyk Kenesh". The latest fare increases occurred in 1999 on Bishkek Public Transport - 3 som on bus and trolley services, and 5 som - minibus, and it remained at this level until 2009 when it was increased to cover some of the increased costs. However, the new level of tariff does not cover operating costs and the issue needs to be reconsidered on a regular basis until fares compensate the operators for the services provided. From this point of view it is obvious that the bus companies need a subsidy from public purse for both capital projects and operational costs.

According to the last resolution of the city parliament, dated 29 December 2009 No. 138, the right to free travel for municipal vehicles established in the following categories of citizens: pensioners, disabled I, II, III group, disabled since childhood, children under seven. In addition, postmen and policemen have the right to use municipal vehicles for free. This is a core problem of municipal operators which caused a shortage of income. Municipal operators are compensated for extent and concessionary travellers, but compensation mostly does not occur in time and in not enough volume.

Despite cutting the number of extent and concessionary passengers to four from thirty previously, municipal companies still face financial deficits from fare 


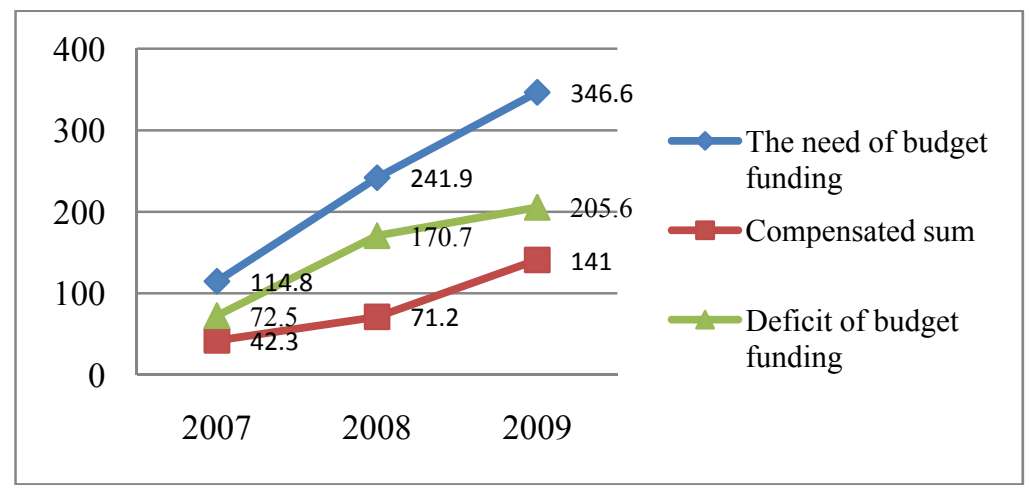

Source: Bishkek City Transport Department

Figure 3: Financial statement of municipal public transport companies (som/KGS, thousand).

collection as well as from compensation (figure 2). They are compensated partly by central government and the rest by local government. As figure 2 shows, with a huge amount of fiscal deficit, municipal companies are not able to cover operation costs and function properly.

Public transport cannot be "profitable" because, as service increases, fixed costs (average total costs - salaries, maintenance, supplies, operations, and debt service) usually increase by a greater amount [6]. In 2001, The World Bank estimated that the fares of Bishkek municipal public transport companies cover only 50 percent of costs) and, in addition, companies operating large vehicles are required to grant privileges to large segments of the population, which only in a few cases are compensated by the municipality [21]. To date, as we estimated according to data of BCTP, fares rarely cover 50 percent of costs even less, and for the August 2010 loss of municipal public transport enterprises accounted nearly fifty million KGS. The total revenue received including compensation must be sufficient to cover all costs but to reach this goal they need to reconsider the tariff system and government subsidies. The percentage of passengers entitled to free travel $P f$ on municipal vehicles reaches 50 per cent, including concessionaries. This can be formulised in the following equation:

$$
P f=\frac{\mathrm{Npf}}{\mathrm{V}} \times 100 .
$$

where:

$\mathrm{N}_{\mathrm{pf}}-$ number of passengers entitled to free travel

$\mathrm{V}$ - volume of whole passengers

Indeed, while travelling on the municipal bus, number line 19, it was identified that half of the passengers do not pay for the service, this can be regarded also to other buses or trolleybuses as drivers confirmed themselves. 
Access to the financial statement of private operators is not allowed, therefore we have not shown in this paper. As private operators do not carry out extent and concessionary passengers, they are able to possess an advantage over public operators that could lead to a positive indicator in the balance sheet. But as practice shows, the renewal of fleet in the private companies happens very rarely, they still continue to provide services with old, poorly maintained and potentially dangerous vehicles, i.e. minibuses.

\section{Conclusion}

The private minibus sector met the demand of consumers in Bishkek after 1990 and made a vital contribution to the public transport supply in the years when the big buses disappeared from the city lines. The private sector set up its place in the market itself successfully functioning without any government support. But as a result of reform which started in 2008, carriage of total volume of passengers of minibus service has declined sharply after the re-emerged new big bus sector. A number of minibuses were diminished from core routes in the centre and replaced to suburbs. This caused a decline in their operation income. This decision seems adequate from an ecological point of view; also considered as a positive step in improving the quality of service as the majority of minibuses are aged. However, the minibus sector is unlikely to disappear from the transport market in the next few years as the bus sector is unable to cover the level of minibus performance. There is a limit of city and government budget to purchase the needed number of vehicles (bus, trolleybus) in order to meet the demand of residents and non-resident travellers. The numbers of needed buses for meeting the demand are 500-600, trolleybuses 300-400 [9].

Hence, the Government has a reliable basis on which to project future needs in order plan improvements in the public transport sector in accordance with passenger expectations. Some of these improvements can be described as:

- $\quad$ increasing in number the bus and trolleybus fleet, physical access for the disabled should be taken into account

- $\quad$ have an effective tariff policy

- $\quad$ extend the time when public transport is available

- $\quad$ extend subsidy

It is clear that public transport is becoming one of the most important tasks of the social sphere creating enormous challenges to city authorities. Currently, Bishkek is suffering from traffic congestion caused by private car ownership which has been growing year-by-year. It is requested by public transport users that bus priority must be located in the core centre or where is needed. It is necessary to give an importance on the outlines mentioned above and work on them effectively. These issues should be considered by members of the city council and redesign the land use both for public transport and motorcars. In addition, it is important to raise a concern about subsidies demanded by public transport, both for capital and operating costs. It is well known that the subsidy 
is the backbone for public transport functioning continuously. As soon as the subsidies on public transport are concerned along the effective tariff policy, the fleet renewal plan would be able to take place. This in turn will more or less affect the level and nature of the demand for public transport positively as our demand for travel is increasing day-to-day.

It is necessary to say that in the Kyrgyz Republic, despite the law regulation for disabled people on public transport, physical access to public transport is not allowed, i.e. there are no vehicles designed for them. Moreover, they are not able to move freely in the street due to a lack of infrastructure designed especially for the disabled. It is important to take into account the physical access of disabled to public transport vehicles while working on projects of urban public transport improvements in perspective. The approach of Brno Public Transport in the Czech Republic can be an example in terms of making public transport services feasible and easily accessible for all riders [10, 20].

\section{References}

[1] Simpson B.J., Urban Public Transport Today, E\&FN Spon: London, pp. 18, 1994

[2] Pucher J., Hyungyong Park \& Kim M.H., Public Transport Reforms in Seoul: Innovations Motivated by Funding Crisis/Journal of Public Transportation. Journal of Public Transportation, Vol.8, No. 5, pp. 41-62, 2005

[3] Kumslov G.V., Puti usilenia vozdeistvia rynochnyh mechanizmov v stabilizatcii protcessov vnutrennei migratcii naselenia Kyrgyzstana (Ways of strengthening impact of market mechanisms in stabilization of internal migration process in Kyrgyzstan). Vestnik of Kyrgyz-Russian Slavic University/No. 3, 2002.

[4] Iles R., Public Transport in Developing Countries (Chapter 1). Topics in Problems and Characteristics of Public Transport in Developing Countries, Elsevier: Amsterdam, pp. 7-28, 2005

[5] Arakelyan A., Planning, Budgeting and Management of Urban Public Transit in Yerevan. Contribution to Managing and financing urban public transport systems/and international perspective, ed. Guess G.M., OSI/LGI: Budapest, pp. 39-88, 2008

[6] Guess G.M., (ed). Managing and financing urban public transport systems/an international perspective, OSI/LGI: Budapest, pp. 1-39, 2008

[7] Schiefelbusch M. \& Dienel H.L., (eds). Public Transport and its Users/The passenger's Perspective in Planning and Customer Care, Ashgate: England, pp. 7-9, 2009

[8] Finn B., Transition From Public Monopoly to Controlled Competition in a Post Socialist Economy - Experience in the Republic of Kazakhstan, Selected Papers from the $9^{\text {th }}$ International Conference (Thredbo 9), Lisbon, September, pp. 659-676, 2005

[9] Totalina G.A., Personal communication, 7-8 September 2010, Economist of Bishkek City Transport Department, Bishkek, Kyrgyzstan. 
[10] Jarolin Z., Personal communication, 26 November 2009, Technical manager of Brno City Transport Company (Dopravní podnik města Brna), Brno, Czech Republic.

[11] Akimov A. \& Banister D., Urban transport in post-communist transition. The case of Tashkent, Uzbekistan/Working paper No. 1052, Oxford University, 2010, Online. http://www.tsu.ox.ac.uk/pubs/1052-akimov.pdf

[12] Bolotov E.A., Tezekbaev T.S., Akmatbek R., Shakiralieva N.E., Ekologicheskie problemy i zagriaznenie vybrosov avtomobilnogo transporta pochvy i vody (Environmental problems and pollution emissions of road transport into soil and water body), Online.http://arch.kyrlibnet.kg /uploads/BOLOTOV\%20E.A.,\%20TEZEKBAEV\%20T.C.,\%20AKMATB EK\%20UULU\%20R.,\%20SHAKIRALIEVA\%20N.E..pdf

[13] Gwilliam K, Bus Franchising in Developing Countries: Some Recent World Bank Experience, 2005, Online. http://siteresources.worldbank.org /INTURBANTRANSPORT/Resources/bus_franch_gwilliam.pdf

[14] Hedges C.A., The Potential of Entrepreneurial Urban Public Transport in Transition Economies, Online. www.seedcenter.gr/projects/MNE $/ 1$ stconfer/1stconf_papers/Hedges.pdf

[15] Kominek Z., Filling the gap in urban transport: Private sector participation in transition countries, EBRD/Working paper No. 93-2005. Online.http://www.ebrd.com/downloads/research/economics/workingpaper s/wp0093.pdf

[16] Rahimov R., Internal Migration in the context of land relations, Online.http://src.auca.kg/images/stories/files/Rahimov_eng.pdf

[17] Agency for city development of Bishkek, www.arg.kg

[18] Kyrgyz legislation, www.online.toktom.kg

[19] Kyrgyz National Statistic Committee, www.stat.kg

[20] Dopravní podnik města Brna, www.dpmb.cz

[21] World Bank, A World Bank Country Study: Kyrgyz Republic - Fiscal Sustainability Study, Washington, DC., The World Bank, 2001 